\title{
PENGARUH KOMPETENSI, PEMANFAATAN TEKNOLOGI INFORMASI, KOMITMEN DAN REVISI ANGGARAN PADA EFEKTIVITAS PENGELOLAAN ANGGARAN UNIVERSITAS UDAYANA
}

\author{
I Wayan Sukarta ${ }^{1}$ \\ I Dewa Nyoman Badera² \\ Ni Made Dwi Ratnadi ${ }^{3}$
}

${ }^{1}$ Fakultas Ekonomi dan Bisnis Universitas Udayana, Bali, Indonesia
${ }^{1}$ e-mail: iwayansukarta@ @mail.com
${ }^{2}$ Fakultas Ekonomi dan Bisnis Universitas Udayana, Bali, Indonesia
${ }^{3}$ Fakultas Ekonomi dan Bisnis Universitas Udayana, Bali, Indonesia

\begin{abstract}
ABSTRAK
Penelitian ini bertujuan untuk mendapatkan bukti empiris pengaruh kompetensi sumber daya manusia, pemanfaatan teknologi informasi, komitmen organisasi dan revisi anggaran pada efektivitas pengelolaan anggaran Universitas Udayana. Sumber data yang digunakan adalah data primer yang diperoleh melalui kuesioner. Responden adalah seluruh pejabat pengelola anggaran yang ada dalam lingkungan Universitas Udayana tahun 2016 sebanyak 156 orang. Teknik analisis data menggunakan regresi linear berganda. Hasil analisis menunjukkan bahwa kompetensi sumber daya manusia berpengaruh positif pada efektivitas pengelolaan anggaran, pemanfaatan teknologi informasi berpengaruh positif pada efektivitas pengelolaan anggaran, komitmen organisasi berpengaruh positif pada efektivitas pengelolaan anggaran dan revisi anggaran berpengaruh positif pada efektivitas pengelolaan anggaran Universitas Udayana.
\end{abstract}

Kata kunci: kompetensi, pemanfaatan teknologi informasi, komitmen, revisi anggaran, efektivitas pengelolaan anggaran.

\begin{abstract}
This study aimed to get empirical evidence of the influence of human resources competence, utilization of information technology, organizational commitment and budget revision on the effectiveness of Udayana University budget management. Data source used are primary data obtained through questionnaires. The respondents were all over the existing budget management officer of Udayana University in 2016 as many as 156 peoples. Data analysis technique used multiple linear regression. The analysis showed that the human resources competencies positive influence on the effectiveness of budget management, utilization of information technology positive influence on the effectiveness of budget management, organizational commitment positive influence on the effectiveness of budget management and budget revision positive influence on the effectiveness of Udayana University budget management.
\end{abstract}

Keywords: competence, utilization of information technology, commitment, budget revision, effectiveness of budget management 


\section{PENDAHULUAN}

Reformasi pengelolaan keuangan negara ditandai dengan dikeluarkannya 3 (tiga) paket Undang-Undang di bidang Keuangan Negara yang meliputi: Undangundang Nomor 17 Tahun 2003 tentang Keuangan Negara, Undang-Undang Nomor 1 Tahun 2004 tentang Perbendaharaan Negara, Undang-Undang Nomor 15 Tahun 2004 tentang Pemeriksaan Pengelolaan dan Tanggung Jawab Keuangan Negara. Salah satu implikasi 3 (tiga) paket Undang-Undang tersebut mengamanahkan agar setiap instansi pemerintah dpt mengelola anggarannya secara efektif.

Efektivitas dalam pengelolaan anggaran meliputi penyelesaian kegiatan tepat pada waktunya dan di dalam batas anggaran yang tersedia, dapat berarti pula pencapaian tujuan dan sasaran yang telah direncanakan (Halim, 2004:74).) Efektifitas merupakan suatu perbandingan antara target dan hasil yang telah tercapai, semakin mendekatinya antara target dan hasil yang dicapai maka semakin efektif suatu perencanaan (Mardiasmo, 2009).

Untuk mengetahui seberapa efektif suatu anggaran adalah dengan mengukur tingkat efektivitasnya (Mahsun, 2009). Dalam hal ini efektifitas dihitung dengan formula sebagai berikut:

Efektifitas $=($ Realisasi Anggaran Belanja $) /($ Target Anggaran Belanja $) \times 100 \%$.

Adapun kriteria tingkat efektifitas menurut keputusan Menteri Dalam Negeri Nomor 690.900-327 Tahun 1996 adalah sebagai berikut: (a) Jika hasil perbandingan lebih dari 100\%, maka anggaran belanja dikatakan sangat efektif; (b) Jika hasil pencapaian antara 90\% - 100\%, maka anggaran belanja dikatakan efektif; (c) Jika hasil pencapaian antara 80\% - 90\%, maka anggaran belanja dikatakan cukup efektif; (d) Jika hasil pencapaian antara 60\% - 80\%, maka anggaran belanja 
dikatakan kurang efektif; (e) Jika hasil pencapaian dibawah 60\%, maka anggaran belanja dikatakan tidak efektif.

Salah satu isu yang menjadi sorotan dewasa ini terkait dengan pengelolaan anggaran adalah belum efektifnya pengelolaan anggaran, baik pada Pemerintah Pusat maupun Daerah, tidak terlepas Universitas Udayana sebagai salah satu instansi pusat yang mengelola APBN. Belum efektifnya pengelolaan anggaran tercermin dari rendahnya penyerapan anggaran (Fahlevi dan Ananta, 2015). Rendahnya penyerapan anggaran merupakan salah satu faktor penting yang berpengaruh pada efektivitas pengelolaan anggaran (Rahayu dan Siswanto, 2010; World Bank, 2012).

Universitas Udayana merupakan salah satu Perguruan Tinggi Negeri (PTN) yang menerapkan Pola Keuangan Badan Layanan Umum (BLU) yang secara resmi telah memperoleh status BLU penuh pada tanggal 27 Desember 2011 berdasarkan Keputusan Menteri Keuangan No. 441/KMK.05/2011 yang memberikan fleksibilitas pengelolaan keuangan. Salah satu fleksibilitas dalam pengelolaan keuangan BLU adalah dapat digunakannya secara langsung Penerimaan Negara Bukan Pajak (PNBP) oleh Kuasa Pengguna Anggaran (KPA) tanpa harus disetorkan ke kas Negara terlebih dahulu seperti satuan kerja biasa. Dengan demikian PTN BLU idealnya sudah dapat melaksanakan anggarannya sejak awal tahun sehingga dapat mencapai realisasi anggaran belanja yang maksimum serta sasaran dan tujuan dapat terealisasi sesuai dengan yang ditargetkan. Namun sampai dengan realisasi anggaran tahun 2015 Universitas Udayana belum dapat mencapai pengelolaan anggaran yang efektif. 
I Wayan Sukarta, I Dewa Nyoman Badera dan Ni Made Dwi Ratnadi. Pengaruh

Adapun gambaran mengenai tingkat efektivitas pengelolaan anggaran pada Universitas Udayana tahun 2012 sampai dengan 2015 dapat disajikan seperti Tabel 1.

Tabel 1

Anggaran dan Realisasi Belanja Universitas Udayana Tahun 2012 - 2015

\begin{tabular}{cccc}
\hline Tahun Anggaran & $\begin{array}{c}\text { Anggaran Belanja } \\
(\mathbf{R p})\end{array}$ & Realisasi Belanja (Rp) & $\begin{array}{c}\text { Tingkat } \\
\text { Efektivitas (\%) }\end{array}$ \\
\hline 2012 & 581.935 .234 .000 & 482.591 .739 .625 & 82,93 \\
2013 & 559.899 .437 .000 & 441.758 .099 .817 & 78,90 \\
2014 & 634.742 .798 .000 & 495.533 .223 .649 & 78,07 \\
2015 & 542.331 .104 .000 & 485.927 .386 .676 & 89,60 \\
\hline
\end{tabular}
Sumber: LRA Bagian Keuangan BAUK Unud (Data Diolah, 2016)

Pada Tabel 1.1 dapat diketahui bahwa realisasi anggaran Universitas Udayana tahun 2012-2015 belum dapat dikatakan efektif karena tingkat efektivitasnya masih berada dibawah $90 \%$.

Jika ditelusuri lebih jauh indikasi masih belum efektifnya pengelolaan anggaran pada Universitas Udayana, salah satunya diduga disebabkan oleh Kompetensi Sumber Daya Manusia pengelola anggaran yang belum memadai. Berdasarkan hasil evaluasi faktor Internal terhadap bidang Tata Kelola Universitas Udayana dalam Renstra Unud 2015-2019 dinyatakan bahwa kemampuan staf di bidang perencanaan dan pengelolaan keuangan masih lemah. Gejala kelemahan ini nampak pada pemahaman penyusunan kertas kerja perencanaan dan persepsi tentang pengelolaan keuangan yang berbasis BLU (Renstra Unud, 2015). Penelitian empiris mengenai pengaruh Kompetensi Sumber Daya Manusia pada efektivitas pengelolaan anggaran pernah dilakukan oleh Dewi (2010), Yaswat (2015) dan Iskandar (2015) yang menunjukkan hasil bahwa Kompetensi Sumber Daya Manusia berpengaruh positif pada efektivitas pengelolaan keuangan daerah. 
Hal kedua yang diduga mempengaruhi efektivitas pengelolaan anggaran Universitas Udayana adalah pemanfaatan teknologi informasi. Komputer sebagai salah satu komponen dari teknologi informasi merupakan alat yang bisa melipatgandakan kemampuan yang dimiliki manusia dan komputer juga bisa mengerjakan sesuatu yang manusia mungkin tidak mampu melakukannya (Jogiyanto, 2003). Komputer merupakan bagian terpenting dari teknologi informasi akan sangat membantu peningkatan kualitas dari informasi (Husein, 2003). Teknologi informasi berkaitan dengan aplikasi komputer dan peralatan telekomunikasi untuk menyimpan, mengambil, mengirim dan memanipulasi data (Lim, 2013:93). Penelitian Donnelly et al., (1994) menemukan bahwa sistem/teknologi informasi yang dimiliki pemerintah daerah di Skotlandia belum begitu baik. Hal ini boleh jadi dialami juga oleh Universitas Udayana sebagaimana hasil evaluasi faktor Internal terhadap bidang tata kelola yang tertuang dalam Rencana Strategis Universitas Udayana 2015-2019 yang menyatakan bahwa Sistem Informasi terpadu belum dikelola dengan baik. Penelitian sebelumnya telah dilakukan oleh Andriani (2010) yang menunjukkan hasil bahwa pemanfaatan teknologi informasi berpengaruh positif terhadap ketepatwaktuan laporan keuangan pemerintah daerah Kabupaten Pesisir Selatan. Hullah (2012) menemukan hasil bahwa Pemanfaatan Teknologi Informasi berpengaruh positif terhadap Keterandalan Pelaporan Keuangan Pemerintah Provinsi Sulawesi Utara. Penelitian yang dilakukan oleh Riyanti (2015) membuktikan bahwa pemanfaatan teknologi informasi berpengaruh positif terhadap efektivitas penyusunan laporan keuangan satuan kerja Mahkamah Syar'iyah di Aceh. Hasil penelitian ini sejalan dengan penelitian yang dilakukan oleh Grant et al. (2008). Selanjutnya Pratikyo (2016) 
menemukan hasil Teknologi Informasi berpengaruh positif terhadap kinerja Manajerial Perusahaan Manufaktur di Kabupaten Pati.

Hal ketiga yang diduga mempengaruhi efektivitas pengelolaan anggaran Universitas Udayana adalah Komitmen Organisasi. Komitmen organisasi menunjukkan keyakinan dan dukungan serta loyalitas seseorang terhadap nilai dan sasaran yang ingin dicapai organisasi (Mowday et al., 1979). Dengan komitmen organisasi akan memdorong diri individu untuk mencapai keberhasilan organisasi sesuai dengan tujuan yang ditetapkan (Wiener, 1982). Lebih lanjut Sumarno (2005) dalam Yuniarti dan Saty (2008) menyatakan bahwa komitmen organisasi yang kuat akan mendorong individu berusaha keras untuk mencapai tujuan organisasi. Sedangkan komitmen organisasi yang rendah akan menyebabkan individu tersebut hanya mementingkan dirinya sendiri atau kelompoknya sehingga pada akhirnya kinerja individu tersebut akan rendah pada organisasinya (Angel dan Perry,1981; Porter et. al., 1974). Penelitian tentang pengaruh komitmen organisasi pada efektivitas pengelolaan anggaran telah dilakukan oleh Jasman (2012), hasilnya menunjukkan bahwa komitmen organisasi berpengaruh positif terhadap efektivitas pengelolaan anggaran. Azmi (2014) melakukan penelitian tentang pengaruh komitmen organisasi terhadap Kinerja Pengelolaan Keuangan Daerah di Lingkungan Pemerintah Aceh yang menunjukkan hasil komitmen organisasi berpengaruh positif terhadap kinerja pengelolaan keuangan daerah. Sumarno (2005) meneliti tentang Pengaruh Komitmen Organisasi terhadap hubungan antara Partisipasi Anggaran dan Kinerja Manajerial, hasilnya menunjukkan bahwa komitmen organisasi berpengaruh positif secara statistik terhadap hubungan antara partisipasi anggaran dan kinerja manajerial. Adamy (2010) dan Baihaqi (2012) 
juga meneliti tentang pengaruh komitmen organisasi terhadap Kinerja Manajerial, hasilnya juga membuktikan bahwa komitmen organisasi berpengaruh positif terhadap Kinerja Manajerial.

Hal keempat yang diduga berpengaruh pada efektivitas pengelolaan anggaran Universitas Udayana adalah revisi anggaran. Dalam Peraturan Menteri Keuangan Nomor 15 Tahun 2016 tentang Tata Cara Revisi Anggaran, menyatakan bahwa dalam rangka meningkatkan efisiensi dan efektivitas pelaksanaan anggaran belanja pemerintah tahun anggaran berkenaan serta percepatan pencapaian kinerja kementerian/lembaga, perlu dilakukan perubahan (revisi) atas rincian anggaran belanja pemerintah pusat. Perencanaan anggaran yang disusun satu tahun sebelumnya, sangat dimungkinkan belum mencakup seluruh kebutuhan untuk tahun yang direncanakan. Penelitian sebelumnya tentang pengaruh revisi anggaran telah dilakukan oleh Indiana (2010) yang menunjukkan hasil bahwa Revisi anggaran berpengaruh positif terhadap pencapaian anggaran yang efektif pada Perusahaan-Perusahaan Manufaktur di Klaten. Penelitian terkait berikutnya dilakukan oleh Yeyen (2013) yang menemukan hasil Revisi Anggaran berpengaruh positif terhadap Pencapaian Anggaran yang Efektif pada Pemerintah Kota Payakumbuh.

Pemahaman bahwa ada indikasi pengelolaan anggaran pada Universitas Udayana yang belum efektif yang tercermin dari varian antara realisasi dengan anggaran yang masih relatif tinggi, pola realisasi anggaran yang masih terkonsentrasi pada semester II setiap tahunnya dan berdasarkan fenomena yang dapat diamati maka penulis tertarik untuk melakukan penelitian mengenai variabelvariabel yang diduga berpengaruh pada efektivitas pengelolaan anggaran 
Universitas Udayana. Pemahaman pada variabel-variabel tersebut diharapkan akan bermanfaat bagi pengambil kebijakan dalam mengambil keputusan mengenai upaya-upaya yang dapat dilakukan untuk meningkatkan efektivitas pengelolaan anggaran.

Berdasarkan Latar Belakang di atas, maka yang menjadi pokok permasalahan dalam penelitian ini adalah: (a) Apakah Kompetensi Sumber Daya Manusia berpengaruh pada efektivitas pengelolaan anggaran; (b) Apakah Pemanfaatan Teknologi Informasi berpengaruh pada efektivitas pengelolaan anggaran; (c) Apakah Komitmen Organisasi berpengaruh pada efektivitas pengelolaan anggaran; (d) Apakah Revisi Anggaran berpengaruh pada efektivitas pengelolaan anggaran. Berkaitan dengan permasalahan yang telah dirumuskan, maka tujuan penelitian ini adalah untuk mengetahui dan mendapatkan bukti empiris: (a) pengaruh Kompetensi Sumber Daya Manusia pada efektivitas pengelolaan anggaran; (b) pengaruh pemanfaatan Teknologi Informasi pada efektivitas pengelolaan anggaran; (c) pengaruh Komitmen Organisasi pada efektivitas pengelolaan anggaran; (d) pengaruh Revisi Anggaran pada efektivitas pengelolaan Anggaran. Hasil penelitian ini dapat memberikan kontribusi terhadap pengembangan ilmu pengetahuan sektor publik, bidang akuntansi pemerintahan, khususnya terkait efektivitas pengelolaan anggaran, serta memperoleh pemahaman yang lebih baik terkait dengan teori penatalayanan/pengelolaan (stewardship). Hasil penelitian ini juga dapat memberikan sumbangan pemikiran bagi organisasi dalam pembuatan kebijakan yang berkaitan dengan usaha meningkatkan efektivitas pengelolaan anggaran, dengan mempertimbangkan faktor-faktor yang mempengaruhi efektivitas pengelolaan anggaran tersebut. 
Grand theory yang mendasari penelitian ini adalah bagian dari agency theory yaitu stewardship theory yang dikemukakan oleh Donaldson et al. (1997). Teori stewardship menggambarkan situasi dimana manajemen tidaklah termotivasi oleh tujuan-tujuan individu tetapi lebih ditujukan pada sasaran hasil utama mereka untuk kepentingan organisasi. Pada sektor swasta para penganut teori stewardship berpendapat bahwa apabila manajer-manajer pada tingkat yang lebih tinggi sebagai contoh CEO yang bertindak sebagai steward akan mempunyai sikap proorganisasional pada saat struktur manajemen perusahaan memberikan otoritas dan keleluasaan yang tinggi (Donaldson dan Davis, 1989, 1991). Teori stewardship dapat diterapkan pada penelitian akuntansi organisasi sektor publik seperti organisasi pemerintahan (Morgan, 1996; Van Slyke, 2006 dan Thorton, 2009) dan non profit lainnya (Vargas, 2004; Caers Ralf, 2006 dan Wilson, 2010). Berdasarkan teori ini maka manajemen pemerintahan dituntut untuk memberikan pelayanan (bertindak sebagai steward/pelayan) bagi kepentingan principal yaitu masyarakat dan inastansi. Dengan demikian manajemen di lingkungan pemerintahan lebih dominan bertindak sebagai steward dibandingkan sebagai agent.

Penelitian ini didesain untuk menguji pengaruh empat variabel bebas Kompetensi Sumber Daya Manusia, Pemanfaatan Teknologi Informasi, Komitmen Organisasi dan Revisi Anggaran pada variabel terikat Efektivitas Pengelolaan Anggaran. Konsep yang menjelaskan hubungan antar variabel, disajikan pada Gambar 1.

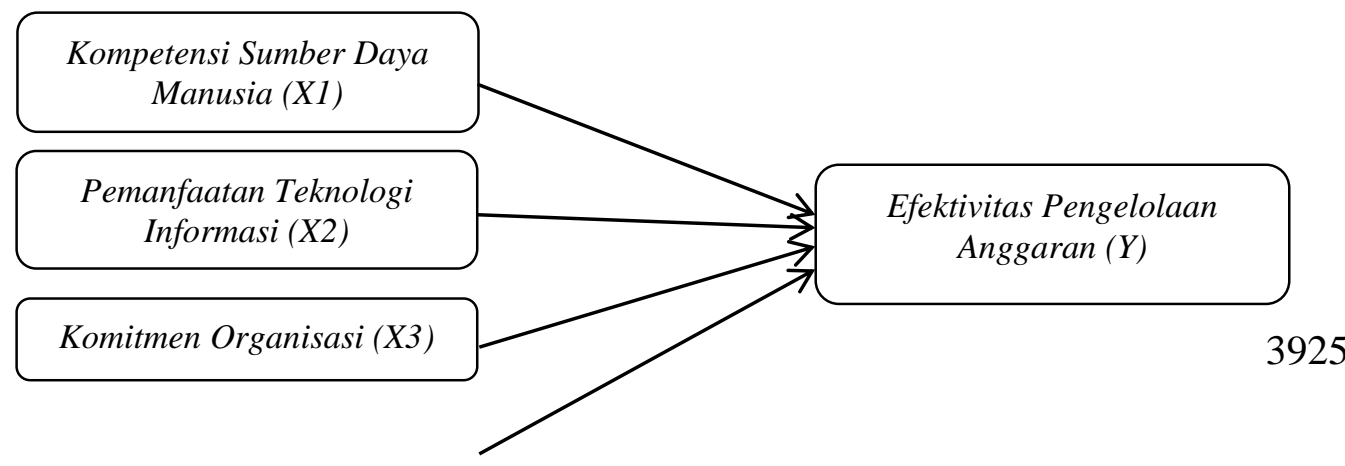


Revisi Anggaran (X4)

\section{Gambar 1. Konsep Penelitian}

Berdasarkan Stewardship Theory yang menyatakan bahwa manajer menengah di organisasi pemerintahan lebih banyak bersikap sebagai steward daripada agent yang menyebabkan kinerja organisasi dapat ditingkatkan, demikian juga Universitas Udayana dimana sumber daya manusia pengelola anggaran yang terdiri dari pejabat level menengah dan bawah pada masing-masing unit kerja akan meningkatkan efektivitas pengelolaan anggaran jika mereka bersikap sebagai steward. Untuk melaksanakan tanggungjawab pengelolaan anggaran, maka stewards (pengelola anggaran) akan mengerahkan semua kompetensi yang dimilikinya. Dewi (2010) memberikan bukti bahwa Kompetensi Sumber Daya Manusia berpengaruh positif secara statistik pada Efektivitas Pengelolaan Keuangan Daerah Kabupaten Badung. Hasil penelitian ini sejalan dengan penelitian yang dilakukan oleh Yaswat (2015) yang menyatakan bahwa kompetensi sumber daya manusia berpengaruh positif terhadap efektivitas pengelolaan keuangan Daerah Kabupaten Tanah Datar Provinsi Sumatera Barat. Paparan diatas memberikan makna bahwa kompetensi Sumber Daya Manusia yang makin meningkat akan berakibat meningkatnya efektivitas pengelolaan anggaran. Berdasarkan Stewardship Theory dan bukti empiris tersebut diduga terdapat hubungan positif antara Kompetensi Sumber Daya Manusia dengan Efektivitas Pengelolaan Anggaran sehingga penulis mengajukan hipotesis: 
$\mathrm{H}_{1}$ : Kompetensi Sumber Daya Manusia berpengaruh positif pada efektivitas pengelolaan anggaran.

Berdasarkan Stewardship Theory, Perguruan Tinggi selaku steward dipandang sebagai suatu lembaga yang dapat dipercaya untuk bertindak sesuai kepentingan publik, dengan melaksanakan tugas dan fungsinya dengan tepat dalam merencanakan dan melaksanakan anggaran yang diamanahkan kepadanya, para pengelola anggaran akan bekerja dengan sebaik-baiknya untuk kepentingan principal yaitu masyarakat dan instansi mereka. Untuk melaksanakan tanggung jawab tersebut, maka stewards (pengelola anggaran) mengerahkan semua kemampuan dan keahliannya untuk meningkatkan efektivitas pengelolaan anggaran, salah satunya dengan pemanfaatan teknologi informasi sehingga dokumen perencanaan dan pelaksanaan anggaran dapat diwujudkan tepat waktu.

Penelitian sebelumnya tentang pengaruh pemanfaatan teknologi informasi telah dilakukan oleh Andriani (2010) yang menunjukkan hasil bahwa pemanfaatan teknologi informasi berpengaruh signifikan terhadap ketepatwaktuan laporan keuangan pemerintah daerah Kabupaten Pesisir Selatan. Hullah (2012), menemukan hasil bahwa secara parsial dan simultan Pemanfaatan Teknologi Informasi berpengaruh terhadap Keterandalan Pelaporan Keuangan Pemerintah Provinsi Sulawesi Utara. Berdasarkan Stewardship Theory dan bukti empiris tersebut diduga terdapat hubungan positif antara pemanfaatan teknologi informasi dengan efektivitas pengelolaan anggaran, sehingga penulis mengajukan hipotesis sebagai berikut:

$\mathrm{H}_{2}$ : Pemanfaatan Teknologi Informasi berpengaruh positif pada efektivitas pengelolaan anggaran. 
Berdasarkan Stewardship Theory dimana manajemen tidaklah termotivasi oleh tujuan-tujuan individu tetapi lebih ditujukan pada sasaran hasil utama mereka untuk kepentingan organisasi maka pegawai akan lebih mementingkan kepentingan organisasi dari pada kepentingan pribadi. Penelitian tentang pengaruh komitmen organisasi pada efektivitas pengelolaan anggaran telah dilakukan oleh Jasman (2012), hasilnya menunjukkan bahwa komitmen organisasi berpengaruh positif dan signifikan terhadap efektivitas pengelolaan anggaran. Azmi (2014) melakukan penelitian tentang pengaruh komitmen organisasi terhadap Kinerja Pengelolaan Keuangan Daerah di Lingkungan Pemerintah Aceh yang menunjukkan hasil komitmen organisasi berpengaruh terhadap kinerja pengelolaan keuangan daerah. Berdasarkan Stewardship Theory dan bukti empiris tersebut diduga terdapat hubungan positif antara Kompetensi Sumber Daya Manusia dengan Efektivitas Pengelolaan Anggaran sehingga penulis mengajukan hipotesis:

$\mathrm{H}_{3}$ : Komitmen Organisasi berpengaruh positif pada efektivitas pengelolaan anggaran.

Berdasarkan Stewardship Theory, Perguruan Tinggi selaku steward dipandang sebagai suatu lembaga yang dapat dipercaya untuk bertindak sesuai kepentingan publik, dengan melaksanakan tugas dan fungsinya dengan tepat dalam merencanakan dan melaksanakan anggaran yang diamanahkan kepadanya, para pengelola anggaran akan bekerja dengan sebaik-baiknya untuk kepentingan principal yaitu masyarakat dan instansi mereka, namun ada kalanya perencanaan anggaran yang disusun belum mencakup seluruh kebutuhan untuk tahun yang direncanakan karena dirancang pada satu tahun sebelumnya. Untuk itu dalam rangka kelancaran pelaksanaan anggaran maka stewards (pengelola anggaran) 
perlu melakukan revisi anggaran sehingga anggaran akan menjadi lebih efektif. Penelitian sebelumnya tentang pengaruh revisi anggaran telah dilakukan oleh Indiana (2010) yang menunjukkan hasil bahwa Revisi anggaran berpengaruh positif signifikan terhadap pencapaian anggaran yang efektif pada Perusahaan-Perusahaan Manufaktur di Klaten. Hasil penelitian ini sejalan dengan hasil penelitian yang dilakukan oleh Yeyen (2013) yang menemukan hasil Revisi Anggaran berpengaruh positif terhadap Pencapaian Anggaran yang Efektif pada Pemerintah Kota Payakumbuh. Berdasarkan Stewardship Theory dan bukti empiris tersebut diduga terdapat hubungan positif antara Revisi Anggaran dengan Efektivitas Pengelolaan Anggaran sehingga penulis mengajukan hipotesis:

$\mathrm{H}_{4}$ : Revisi Anggaran berpengaruh positif pada efektivitas pengelolaan anggaran.

\section{METODE PENELITIAN}

Penelitian ini dilaksanakan di Universitas Udayana, Bali tahun 2016. Ruang lingkup penelitian dibatasi pada efektivitas pengelolaan anggaran Universitas Udayana yang akan dijelaskan oleh variabel Kompetensi Sumber Daya Manusia, Pemanfaatan Teknologi Informasi, Komitmen Organisasi dan Revisi Anggaran. Data yang digunakan dalam mendukung penelitian adalah data primer dan data skunder. Data primer diperoleh dengan kuesioner yang ditujukan pada responden (PNS yang menangani pengelolaan anggaran pada Universitas Udayana). Data sekunder berupa data Realisasi Anggaran Pendapatan dan Belanja TA 2012 - 2015.

Populasi dari penelitian ini adalah seluruh Pejabat Pengelola Anggaran BLU Tahun Anggaran 2016 yang ada dalam lingkungan Universitas Udayana terdiri dari 15 orang Pejabat Penandatangan Surat Perintah Membayar (PPSPM), 16 orang 
I Wayan Sukarta, I Dewa Nyoman Badera dan Ni Made Dwi Ratnadi. Pengaruh

Pejabat Pembuat Komitmen (PPK), 16 orang Bendahara Pengeluaran Pembantu (BPP) dan 109 orang anggota BPP, sehingga seluruh populasi berjumlah 156 orang. Penentuan para pejabat tersebut sebagai populasi didasarkan atas pertimbangan bahwa mereka adalah pejabat level atas, tengah dan bawah yang bertanggung jawab pada pengelolaan anggaran, baik perencanaan maupun pelaksanaan pada setiap unit kerjanya. Metode Sampling yang digunakan tergolong dalam Non Probability Sampling. Adapun teknik pengambilan sampel yang digunakan adalah Sampling Jenuh karena peneliti ingin memperoleh kesimpulan umum atau generalisasi dengan tingkat kesalahan yang relatif kecil (Sugiyono, 2014:122). Metode pengumpulan data menggunakan metode survei melalui penyebaran kuesioner. Kuesioner sebelumnya telah lolos uji instrumen berupa uji validitas dan reliabilitas. Seluruh variabel dalam penelitian ini diukur dengan menggunakan skala Likert 5 poin. Variabel yang digunakan dalam penelitian adalah variabel dependen (terikat) dan variabel independen (bebas). Variabel bebas dalam penelitian ini adalah: Kompetensi Sumber Daya Manusia, Pemanfaatan Teknologi Informasi, Komitmen Organisasi, dan Revisi Anggaran. Variabel terikat dalam penelitian ini adalah Efektivitas Pengelolaan Anggaran. Definisi Operasional variabel ditujukan untuk menghindari penafsiran yang berbeda-beda atas variabel dan proksi dari variabel yang akan diteliti. Variabel Kompetensi Sumber Daya Manusia (X1) adalah kemampuan teknis dan operasional yang melekat sebagai pengetahuan dan keterampilan pada seseorang dalam pengelolaan anggaran, dengan indikator dan item pertanyaan yang diadaptasi dari Dewi (2010) yaitu: Latar Belakang Pendidikan, Diklat Teknis, Pengalaman dan Jenjang Pendidikan. Variabel Pemanfaatan Teknologi Informasi (X2) adalah tingkat integrasi teknologi informasi 
pada pelaksanaan tugas-tugas pengelolaan anggaran, dengan indikator dan item pertanyaan yang diadaptasi dari Jurnali dan Supomo (2002) yaitu: Perangkat, Pengelolaan Data Anggaran, dan Perawatan. Variabel Komitmen Organisasi (X3) adalah keyakinan dan dukungan yang kuat terhadap nilai dan sasaran yang ingin dicapai organisasi, dengan indikator dan item pertanyaan yang diadaptasi dari Mowday et al. (1979) yaitu: Identifikasi terhadap nilai-nilai dan tujuan organisasi, Keterlibatan dalam pekerjaan, dan Loyalitas terhadap organisasi. Variabel Revisi Anggaran (X4) adalah perubahan rincian anggaran yang telah ditetapkan dalam DIPA Tahun Anggaran berkenaan dalam rangka meningkatkan efisiensi dan efektivitas pelaksanaan anggaran belanja serta percepatan pencapaian kinerja, dengan indikator dan item pertanyaan yang diadaptasi dari Yeyen (2013) dan Permenkeu nomor: 15/PMK.02/2016 yaitu: penambahan atau pengurangan pagu anggaran, pergeseran rincian anggaran, dan perubahan atau ralat karena kesalahan administrasi. Variabel Efektivitas pengelolaan anggaran Universitas Udayana (Y) adalah tingkat keberhasilan pelaksanaan tugas-tugas perencanaan dan pelaksanaan anggaran baik itu kualitas dan kuantitas, dengan indikator dan item pertanyaan yang diadaptasi dari Dewi (2010) yaitu: ketepatwaktuan, ketepatan realisasi anggaran, dan ketepatan tujuan dan sasaran. Pengujian hipotesis dilakukan dengan menggunakan model Analisis Regresi Linier Berganda yang sebelumnya telah lolos uji asumsi klasik yang meliputi uji normalitas, multikolonearitas, dan heteroskedastisitas dengan menggunakan software SPSS (Statistical Package for Social Science) versi 20.

\section{HASIL DAN PEMBAHASAN}


Pengambilan sampel dalam penelitian ini menggunakan teknik sampling Jenuh, dengan responden seluruh pejabat pengelola anggaran BLU Universitas Udayana tahun 2016 berjumlah 156 org yg tersebar pada unit kerja Kantor Pusat, Fakultas, Program Pascasarjana dan Rumah Sakit Pendidikan. Penyebaran kuesioner dilakukan pada bulan September 2016 dengan cara mengantar dan menjemput hasilnya langsung kepada responden. Semua kuesioner kembali ( response rate $100 \%$ ). Secara keseluruhan, hasil kuesioner dapat digunakan karena data yang disampaikan oleh responden lengkap.

Karakteristik sampel dalam penelitian ini cukup beragam. Responden yang bergender laki-laki sebanyak 75 orang $(48,08 \%)$ sedangkan yang bergender perempuan sebanyak 81 orang $(51,92 \%)$. Kondisi ini menunjukkan bahwa keterlibatan pegawai bergender laki-laki relatif seimbang dengan yang bergender perempuan dalam pengelolaan anggaran. Usia responden 21-30 tahun sebanyak 30 orang $(19,23 \%)$, usia $31-40$ tahun sebanyak 45 orang $(28,85 \%)$, usia $41-50$ tahun sebanyak 50 orang $(32,05 \%)$ dan usia $>50$ tahun sebanyak 31 orang $(19,87 \%)$. Kondisi demikian menunjukkan bahwa pengelola anggaran didominasi oleh pegawai yang memiliki tingkat kematangan yang cukup dalam pengambilan keputusan dari sisi usia. Responden yang berpendidikan SLTA berjumlah 9 orang (5,77\%), Diploma berjumlah 12 orang $(7,69 \%)$, S1 berjumlah 75 orang $(48,08 \%)$, S2 berjumlah 21 orang $(13,46 \%)$, dan S3 berjumlah 39 orang (25\%). Gambaran ini menunjukkan bahwa responden dengan pendidikan Sarjana (S1) memiliki proporsi paling dominan dalam mengelola anggaran Universitas Udayana. Responden yang memiliki latar belakang pendidikan akuntansi sebanyak 29 orang (18,59\%), manajemen sebanyak 28 orang $(17,95 \%)$, Ilmu Ekonomi 6 orang $(3,85 \%)$ dan 
lainnya sebanyak 93 orang $(59,62 \%)$. Kondisi ini menggambarkan bahwa responden yang mengelola anggaran didominasi oleh pegawai dengan latar belakang pendidikan non ekonomi dan non akuntansi. Terdapat sebanyak 20 orang $(12,82 \%)$ responden memiliki pengalaman kerja dibawah 5 tahun, 40 orang $(25,64 \%)$ memiliki pengalaman kerja 5-10 tahun dan 96 orang $(61,54 \%)$ memiliki pengalaman kerja diatas 10 tahun. Kondisi ini menggambarkan bahwa responden yang mengelola anggaran didominasi oleh pegawai yang memiliki pengalaman kerja yang relatif lama. Selanjutnya Terdapat 27 orang $(17,31 \%)$ menyatakan pernah mengikuti Diklat Perencanaan Anggaran, 27 orang (17,31\%) menyatakan pernah mengikuti Diklat Perbendaharaan, 24 orang $(15,38 \%)$ pernah mengikuti Diklat Pelaporan Keuangan dan 17 orang (10,90\%) pernah mengikuti diklat Pengadaan Barang dan Jasa, sementara sisanya sebanyak 61 orang $(39,10 \%)$ menyatakan belum pernah mengikuti jenis diklat pengelolaan anggaran.

Penyajian statistik deskriptif bertujuan untuk menggambarkan karakter sampel serta mendeskripsikan tiap-tiap variabel yang digunakan dalam penelitian. Gambaran karakter sampel dapat dilihat dari nilai maksimum, nilai minimum dan nilai rata-rata (mean) serta deviasi standar. Nilai rata-rata (mean) mencerminkan rata-rata penilaian responden atau kecenderungan jawaban responden untuk tiaptiap variabel yang diteliti. Deviasi Standar merupakan perbedaan nilai data yang diteliti dengan nilai rata-ratanya. Nilai Deviasi Standar yang lebih kecil dari nilai rata-ratanya menunjukkan rendahnya variasi antara nilai maksimum dan minimum selama periode pengamatan atau dengan kata lain tidak ada kesenjangan yang cukup tinggi antara nilai tertinggi dan terendah. Statistik deskriptif dari hasil penelitian dapat dilihat pada Tabel 2 berikut: 
Tabel 2

Statistik Deskriptif

\begin{tabular}{|c|c|c|c|c|c|c|c|}
\hline Variabel & $\mathbf{N}$ & $\begin{array}{c}\text { Jumlah } \\
\text { Pertanyaan }\end{array}$ & $\begin{array}{l}\text { Nilai } \\
\text { Min. }\end{array}$ & $\begin{array}{l}\text { Nilai } \\
\text { Mak. }\end{array}$ & $\begin{array}{l}\text { Rata- } \\
\text { rata }\end{array}$ & $\begin{array}{l}\text { Rata } \\
\text {-rata } \\
\text { skor }\end{array}$ & $\begin{array}{l}\text { Deviasi } \\
\text { Standar }\end{array}$ \\
\hline $\begin{array}{l}\text { Kompetensi } \\
\text { SDM }\end{array}$ & 156 & 4 & 12 & 20 & 16.98 & 4,25 & 2,19 \\
\hline Pemanfaatan TI & 156 & 7 & 21 & 35 & 30.14 & 4,31 & 3,47 \\
\hline $\begin{array}{l}\text { Komitmen } \\
\text { Organisasi }\end{array}$ & 156 & 7 & 21 & 35 & 29.64 & 4,23 & 3,40 \\
\hline $\begin{array}{l}\text { Revisi } \\
\text { Anggaran }\end{array}$ & 156 & 6 & 18 & 30 & 25.41 & 4,24 & 3,00 \\
\hline $\begin{array}{l}\text { Efektivitas } \\
\text { Pengelolaan } \\
\text { Anggaran }\end{array}$ & 156 & 4 & 12 & 20 & 17.18 & 4,30 & 2,29 \\
\hline
\end{tabular}

Tabel 2 menunjukkan bahwa keseluruhan variabel memiliki rata-rata penilaian responden yang cenderung tinggi yang berarti responden memberikan penilaian yang cenderung setuju terhadap indikator tiap-tiap variabel dalam penelitian serta Deviasi Standar yang lebih kecil dari nilai rata-ratanya menunjukkan rendahnya variasi antara nilai maksimum dan minimum selama periode pengamatan.

Untuk memastikan bahwa kuesioner yang digunakan valid dan reliabel, dilakukan uji validitas dan reliabilitas melalui pilot test yang dilakukan sebelum pengumpulan data pada responden yang sesungguhnya, yaitu dengan menyebarkan kuesioner kepada 30 orang mahasiswa Magister Akuntansi Angkatan IV dan V yang menempuh program beasiswa STAR - BPKP. Pemilihan mahasiswa tersebut sebagai pilot test karena mereka merupakan aparatur Pengelola Keuangan Negara pada masing-masing instansi asal mahasiswa, sehingga dapat diasumsikan bahwa mereka pernah terlibat dalam pengelolaan anggaran. Uji validitas dilakukan dengan uji korelasi antara skor tiap-tiap butir pertanyaan dengan total skor dengan kriteria koefisien korelasi harus bernilai minimal 0,3. Hasil uji validitas instrumen menunjukkan keseluruhan koefisien korelasi dari setiap instrumen memiliki nilai 
lebih tinggi dari 0,3 sehingga disimpulkan bahwa instrumen penelitian pada setiap variabel adalah valid. Uji reliabilitas menggunakan uji statistik Cronbach's Alpha dengan kriteria koefisien Cronbach's Alpha harus > 0,7 ((Nunnally, 1994 dalam Ghozali, 2013: 48). Hasil uji reliabilitas menunjukkan bahwa seluruh variabel memiliki nilai cronbach's alpha $>0,7$ sehingga seluruh indikator variabel dalam kuesioner dapat dikatakan reliabel.

Sebelum Model Regresi Berganda digunakan, maka terlebih dahulu dilakukan pengujian asumsi klasik yang bertujuan agar hasil analisis regresi dapat diinterpretasikan dengan akurat atau memenuhi kriteria Best Linear Unbiased Estimator (BLUE). Uji asumsi klasik meliputi uji normalitas, uji multikolonearitas dan uji heteroskedastisitas. Rekapitulasi hasil uji asumsi klasik disajikan pada Tabel 3.

Tabel 3

Hasil Uji Asumsi Klasik

\begin{tabular}{lcccc}
\hline \multirow{1}{*}{ Keterangan } & Uji & \multicolumn{2}{c}{ Uji } & Uji Heteroskedastisitas \\
& Normalitas & \multicolumn{2}{c}{ Multikolonearitas } & (Sig) \\
& & Tolerance & VIF & \\
\hline Kompetensi SDM & & 0,492 & 2,031 & 0,282 \\
Pemanfaatan TI & & 0,431 & 2,318 & 0,737 \\
Komitmen Organisai & & 0,507 & 1,974 & 0,496 \\
Revisi Anggaran & & 0,419 & 2,387 & 0,400 \\
Kolmogorov Smirnov-Z & 0,039 & & & \\
Asymp Sig (2-tailed) & 0,200 & & & \\
Sumber: hasil penelitian (2016) & & &
\end{tabular}

Hasil uji asumsi klasik menunjukkan bahwa variabel dalam penelitian berdistribusi normal, bebas dari multikolonearitas dan heteroskedastisitas. Uji normalitas dilakukan dengan menggunakan uji kolmogorov-smirnov yang menunjukkan signifikansi tiap variabel sebesar 0,200 (lebih tinggi dari $\alpha=0,05$ sehingga dapat dinyatakan data berdistribusi normal). Variabel dalam penelitian ini juga bebas dari multikolonearitas, ditunjukkan dengan nilai Tolerance lebih besar dari 10 persen 
dan nilai VIF tiap variabel lebih kecil 10. Hasil uji Glejser menunjukkan bahwa tidak ada satupun variabel independen yang berpengaruh signifikan terhadap variabel terikat Absolut Residual, sehingga model regresi tidak mengandung adanya heteroskedastisitas. Setelah lolos pengujian asumsi klasik maka langkah selanjutnya dilakukan analisis Regresi Linier Berganda.

Hasil analisis regresi linier berganda disajikan pada Lampiran 4.

Tabel 4

Hasil Analisis Regresi Linier Berganda

\begin{tabular}{|c|c|c|c|c|}
\hline Keterangan & & $\begin{array}{l}\text { Koefisien } \\
\text { Regresi }\end{array}$ & $\mathbf{t}$ & Sig. $\mathbf{t}$ \\
\hline Konstanta & & 0,646 & & \\
\hline Kompetensi Sumber Daya Manusia & & 0,215 & 2,660 & 0,009 \\
\hline Pemanfaatan Teknologi Informasi & & 0,148 & 2,746 & 0,007 \\
\hline Komitmen Organisasi & & 0,141 & 2,976 & 0,003 \\
\hline Revisi Anggaran & & 0,140 & 2,326 & 0,021 \\
\hline Adjusted R Square & $=0,532$ & & & \\
\hline $\mathrm{F}$ & $=45,007$ & & & \\
\hline Signifikan F & $=0,000$ & & & \\
\hline
\end{tabular}

Berdasarkan Tabel 4 dapat ditulis persamaan regresi linier berganda sebagai berikut:

$$
Y=0,646+0,215 X_{1}+0,148 X_{2}+0,141 X_{3}+0,140 X_{4}
$$

Uji goodness of fit menghasilkan nilai $\mathrm{F}_{\text {-hitung }}$ sebesar 45,007 dengan $P_{\text {_value }}$ sebesar $0,000<0,05(\alpha=5 \%)$, dengan demikian model regresi yang digunakan layak uji (fit). Nilai adjusted $\mathrm{R}^{2}$ sebesar 0,532 berarti bahwa sebesar 53,20 persen variasi dari variabel Efektivitas Pengelolaan Anggaran mampu dijelaskan oleh variasi dalam variabel Kompetensi Sumber Daya Manusia, Pemanfaatan Teknologi Informasi, Komitmen Organisasi dan Revisi Anggaran. Sementara itu sisanya sebesar 46,80 persen dipengaruhi oleh variabel lain yang tidak dimasukkan pada model. 
Hasil pengujian hipotesis penelitian menunjukkan bahwa pada taraf nyata 5 persen seluruh variabel bebas yaitu: Kompetensi Sumber Daya Manusia, Pemanfaatan Teknologi Informasi, Komitmen Organisasi dan Revisi Anggaran terbukti berpengaruh positif pada efektivitas pengelolaan anggaran Universitas Udayana.

Hipotesis (1) menyatakan Kompetensi Sumber Daya Manusia berpengaruh positif pada efektivitas pengelolaan anggaran. Hasil pengujian hipotesis menunjukkan bahwa kompetensi sumber daya manusia berpengaruh positif pada efektivitas pengelolaan anggaran. Hasil pengujian hipotesis ini memberikan pemahaman bahwa perubahan pada kompetensi sumber daya manusia akan berpengaruh pada perubahan efektivitas pengelolaan anggaran. Peningkatan kompetensi sumber daya manusia menyebabkan meningkatnya efektivitas pengelolaan anggaran. Berdasarkan hasil survei terhadap latar belakang pendidikan pejabat pengelola anggaran Universitas Udayana Tahun 2016, dari 156 orang pengelola anggaran terdapat sebanyak 29 orang (18,59\%) saja yang berkualifikasi pendidikan bidang Akuntansi, sementara sisanya 127 orang $(81,41 \%)$ berkualifikasi pendidikan Non Akuntansi. Dengan demikian pejabat pengelola anggaran didominasi oleh pegawai dengan latar belakang non akuntansi, sementara itu tugastugas pejabat pengelola anggaran lebih bersifat administrasi teknis yang membutuhkan kompetensi bidang akuntansi sehingga idealnya dijabat oleh pegawai dengan kualifikasi pendidikan akuntansi atau setidaknya jurusan ekonomi. Walaupun sebagian besar pengelola anggaran bukan berlatar belakang pendidikan akuntansi, mereka tetap berusaha untuk mengelola anggaran secara maksimum dengan belajar mandiri, mengikuti aturan-aturan dan Standard Operational 
Procedure (SOP), bertanya kepada yang sudah berpengalaman dan yang sudah mendapatkan diklat pengelolaan anggaran. Dengan masih banyaknya pejabat pengelola anggaran dengan latar belakang pendidikan yang heterogen akan lebih baik jika para pejabat pengelola anggaran yang berkualifikasi pendidikan non akuntansi dalam melanjutkan pendidikannya didorong untuk melanjutkan pada bidang ekonomi atau akuntansi. Hasil Penelitian mendukung Stewardship Theory bahwa manajer menengah di organisasi pemerintahan lebih banyak bersikap sebagai steward daripada agent yang menyebabkan kinerja organisasi dapat ditingkatkan, demikian juga Universitas Udayana dimana sumber daya manusia pengelola anggaran yang terdiri dari pejabat level menengah dan bawah (Dekan, PD II, Kepala Biro, Staf Keuangan) pada masing-masing unit kerja akan meningkatkan efektivitas pengelolaan anggaran jika mereka bersikap sebagai steward. Untuk melaksanakan tanggungjawab pengelolaan anggaran, maka stewards (pengelola anggaran) akan mengerahkan semua kompetensi yang dimilikinya yang meliputi kemampuan teknis dan operasional yang melekat sebagai pengetahuan dan keterampilan dalam pengelolaan anggaran. Hasil penelitian ini sejalan dengan hasil penelitian yang dilakukan oleh Dewi (2010), Andriyani (2010), Herriyanto (2012), Azmi (2014), Malahayati (2015), Yaswat (2015), dan Iskandar (2015) bahwa pengelolaan anggaran akan efektif jika didukung oleh Kompetensi Sumber Daya Manusia yang memadai di bidangnya dengan cara meningkatkan kompetensinya secara berkelanjutan.

Hipotesis (2) menyatakan Pemanfaatan Teknologi Informasi berpengaruh positif pada efektivitas pengelolaan anggaran. Hasil pengujian hipotesis menunjukkan bahwa pemanfaatan teknologi informasi berpengaruh positif pada 
efektivitas pengelolaan anggaran. Hasil pengujian hipotesis ini memberikan pemahaman bahwa peningkatan pemanfaatan teknologi informasi akan berpengaruh pada perubahan efektivitas pengelolaan anggaran. Peningkatan pemanfaatan teknologi informasi menyebabkan meningkatnya efektivitas pengelolaan anggaran.

Hasil survei dan pengamatan peneliti terhadap isian kuesioner disimpulkan bahwa pengelolaan anggaran Universitas Udayana tidak bisa lepas dari pemanfaatan teknologi informasi baik perangkat keras maupun perangkat lunak. Hal ini dapat diketahui dari isian responden terhadap pertanyaan yang penulis ajukan dimana dapat disimpulkan bahwa aktivitas pengelolaan anggaran mulai dari penjaringan data usulan anggaran masing-masing unit kerja, baik rencana pendapatan dan belanja sampai dengan tersusunnya dokumen perencanaan dan pelaksanaan anggaran tidak lepas dari pemanfaatan teknologi informasi yaitu sebagian besar prosesnya menggunakan bantuan komputer, internet dan aplikasi (software). Dokumen perencanaan dan pelaksanaan anggaran tersebut harus dapat diwujudkan tepat waktu, hal ini dapat dicapai dengan peran komponen teknologi (Jogiyanto, 1995).

Hasil Penelitian mendukung Stewardship Theory bahwa Perguruan Tinggi selaku steward dipandang sebagai suatu lembaga yang dapat dipercaya untuk bertindak sesuai kepentingan publik, dengan melaksanakan tugas dan fungsinya dengan tepat dalam merencanakan dan melaksanakan anggaran yang diamanahkan kepadanya, para pengelola anggaran akan bekerja dengan sebaik-baiknya untuk kepentingan principal yaitu masyarakat dan instansi mereka. Untuk melaksanakan tanggung jawab tersebut, maka stewards (pengelola anggaran) 
mengerahkan semua kemampuan dan keahliannya untuk meningkatkan efektivitas pengelolaan anggaran, salah satunya dengan pemanfaatan teknologi informasi sehingga dokumen perencanaan dan pelaksanaan anggaran dapat diwujudkan tepat waktu.

Hasil penelitian ini sejalan dengan hasil penelitian yang dilakukan oleh Andriani (2010), Hullah (2012), Riyanti (2015) dan Pratikyo 2016) yang menyatakan pemanfaatan teknologi merupakan salah satu faktor yang mempengaruhi efektivitas anggaran. Temuan ini membuktikan literatur-literatur yang menyatakan bahwa dengan pemanfaatan teknologi informasi akan menghasilkan informasi yang tepat waktu. Ketepatwaktuan merupakan salah satu dimensi efektivitas pengelolaan anggaran (Sunaryo, 2006).

Hipotesis (3) menyatakan Komitmen Organisasi berpengaruh positif pada efektivitas pengelolaan anggaran. Hasil pengujian hipotesis menunjukkan bahwa komitmen organisasi berpengaruh positif pada efektivitas pengelolaan anggaran. Hasil pengujian hipotesis ini memberikan pemahaman bahwa perubahan pada komitmen organisasi akan berpengaruh pada perubahan efektivitas pengelolaan anggaran. Peningkatan komitmen organisasi menyebabkan meningkatnya efektivitas pengelolaan anggaran. Dalam satu tahun anggaran, pengelola anggaran harus bekerja pararel, melaksanakan anggaran tahun berjalan, melaporkan hasil pelaksanaan anggaran dan sekaligus harus merancang anggaran satu tahun berikutnya, oleh karena itu diperlukan adanya komitmen yang tinggi untuk dapat menyusun dokumen perencanaan dan pelaksanaan anggaran serta melaporkan hasil pelaksanaan anggaran. Apabila semua hal tersebut tidak dilakukan dengan komitmen yang tinggi maka anggaran tidak akan dapat berfungsi sebagaimana 
mestinya. Keberhasilan dalam penyusunan dan pelaksanaan anggaran tergantung pada komitmen masing-masing orang yang terlibat dalam pengelolaan anggaran. Pengelola anggaran yang berkomitmen tinggi terhadap organisasi (Universitas) akan lebih mementingkan kepentingan organisasi daripada kepentingan pribadi yang akan mendorong pengelola anggaran untuk mencapai target anggaran sesuai dengan sasaran yang ingin dicapai oleh organisasi sehingga akan berimplikasi pada efektivitas pengelolaan anggaran. Hasil Penelitian mendukung Stewardship Theory bahwa manajemen tidaklah termotivasi oleh tujuan-tujuan individu tetapi lebih ditujukan pada sasaran hasil utama mereka untuk kepentingan organisasi, sehingga pegawai akan lebih mementingkan kepentingan organisasi daripada kepentingan pribadi. Selain itu, komitmen organisasi dapat merupakan alat bantu psikologis dalam menjalankan organisasinya untuk pencapaian kinerja yang diharapkan (Nouri dan Parker, 1998; Chong dan Chong, 2002; Wentzel, 2002). Hasil penelitian ini sesuai dengan hasil penelitian Modway et al (1979) yang menyatakan bahwa komitmen organisasi menunjukkan keyakinan dan dukungan yang kuat terhadap nilai dan sasaran (goal) yang ingin dicapai organisasi. Dengan adanya komitmen organisasi yang kuat dalam individu akan menyebabkan individu berusaha keras mencapai tujuan organisasi (Sumarno (2005) dalam Yuniarti dan Saty). Hasil penelitian ini sejalan dengan hasil penelitian yang dilakukan oleh Sumarno (2005), Adamy (2010), Baihaqi (2012), Arif (2013), Jasman (2012), dan Azmi (2014) bahwa komitmen organisasi berpengaruh positif pada efektivitas pengelolaan anggaran.

Hipotesis (4) menyatakan Revisi Anggaran berpengaruh positif pada efektivitas pengelolaan anggaran. Hasil pengujian hipotesis menunjukkan bahwa 
I Wayan Sukarta, I Dewa Nyoman Badera dan Ni Made Dwi Ratnadi. Pengaruh

revisi anggaran berpengaruh positif pada efektivitas pengelolaan anggaran Universitas Udayana. Hasil pengujian hipotesis ini memberikan pemahaman bahwa revisi anggaran (peningkatan kualitas anggaran) akan berpengaruh pada perubahan efektivitas pengelolaan anggaran. Revisi anggaran menyebabkan meningkatnya efektivitas pengelolaan anggaran.

Peraturan Menteri Keuangan (Permenkeu) nomor:15/PMK.02/2016 menjamin dilakukannya revisi anggaran. Rincian anggaran pendapatan dan belanja yang sudah tertuang di dalam DIPA tidak tertutup kemungkinan terjadi salah saji dalam penyusunannya, belum mencakup kebutuhan untuk tahun yang direncanakan, terjadi kesalahan prediksi jumlah penerimaan anggaran pendapatan, terjadi perubahan prioritas yang tidak diantisipasi pada saat proses perencanaan, terjadi perubahan metodologi pelaksanaan kegiatan, terjadi optimalisasi rincian belanja yang outputnya sudah tercapai, terjadi perubahan atau penetapan kebijakan Pemerintah dalam tahun anggaran berjalan sehingga dalam rangka efektivitas pelaksanaan anggaran perlu dilakukan revisi. Jika revisi anggaran tidak dilakukan maka anggaran tidak dapat berjalan efektif (Yeyen, 2013).

Permenkeu nomor:15/PMK.02/2016 juga memberikan fleksibilitas dalam revisi anggaran, baik itu revisi yang merupakan kewenangan satuan kerja, kewenangan Kanwil DJPb, maupun kewenangan eselon I dalam hal ini Ditjen Ristek Dikti, namun demikian bukan berarti makin sering direvisi maka anggaran itu makin efektif. Terjadi trade-off dalam revisi anggaran, di satu sisi dengan revisi anggaran akan meningkatkan efektivitas anggaran namun di sisi lain mengindikasikan perencanaan yang kurang baik, khususnya untuk revisi Anggaran yang bersifat pergeseran rincian belanja (tidak menambah/mengurangi pagu 
anggaran) dan frekuensi revisi anggaran juga merupakan salah satu komponen yang berpengaruh pada penilaian Laporan Akuntabilitas Kinerja Insatansi Pemerintah (Lakip). Untuk itu idealnya perlu dilakukan penjadwalan revisi anggaran mengikuti mekanisme APBN dan APBN-P yaitu sebanyak 2 kali dalam satu tahun anggaran, terlebih Universitas Udayana yang memiliki banyak unit kerja yang berbasis pada unit kerja terkecil seperti Program Studi, Lembaga, UPT, Lab dan lainnya yang harus melewati jenjang otorisasi dari tingkat unit kerja sampai konsolidasi di tingkat satuan kerja. Hasil Penelitian mendukung Stewardship Theory bahwa Perguruan Tinggi selaku steward dipandang sebagai suatu lembaga yang dapat dipercaya untuk bertindak sesuai kepentingan publik, dengan melaksanakan tugas dan fungsinya dengan tepat dalam merencanakan dan melaksanakan anggaran yang diamanahkan kepadanya, para pengelola anggaran akan bekerja dengan sebaikbaiknya untuk kepentingan principal yaitu masyarakat dan instansi mereka. Hasil penelitian ini sejalan dengan hasil penelitian yang dilakukan oleh Indiana (2010), Yeyen (2013) yang menyatakan bahwa revisi anggaran berpengaruh positif pada pencapaian anggaran yang efektif.

\section{SIMPULAN DAN SARAN}

Berdasarkan uraian dari rumusan masalah, landasan teori, dan pengujian hipotesis, dapat disimpulkan bahwa kompetensi sumber daya manusia, pemanfaatan teknologi informasi, komitmen organisasi dan revisi anggaran berpengaruh positif terhadap efektivitas pengelolaan anggaran.

Hasil penelitian ini diharapkan dapat menjadi bahan pertimbangan bagi para pembuat kebijakan di Universitas Udayana dalam upaya meningkatkan efektivitas 
I Wayan Sukarta, I Dewa Nyoman Badera dan Ni Made Dwi Ratnadi. Pengaruh

pengelolaan anggaran dapat dilakukan dengan cara: mempertahankan dan meningkatkan kompetensi sumber daya manusia pengelola anggaran melalui peningkatan jumlah pengelola anggaran yang berkualifikasi pendidikan akuntansi, menambah diklat teknis pengelolaan anggaran, meningkatkan jenjang pendidikan serta mempertahankan pejabat pengelola anggaran yang sudah berpengalaman; meningkatkan pemanfaatan teknologi informasi dalam pengelolaan anggaran melalui peningkatan kuantitas dan kualitas teknologi informasi yang meliputi: hardware (perangkat komputer, internet, bandwidth) pada masing-masing unit kerja, software (penggunaan aplikasi komputer dalam pengelolaan anggaran yang sesuai dengan peraturan perundang-undangan), brainware (mengadakan pelatihan aplikasi komputer terkait pengelolaan anggaran) serta perawatan/perbaikan peralatan yang terjadwal secara teratur; meningkatkan komitmen pejabat pengelola anggaran terhadap organisasi dengan internalisasi nilai-nilai dan tujuan organisasi melalui sosialisasi visi, misi, kebijakan strategi, peraturan-peraturan dan nilai-nilai organisasi, menanamkan sikap rasa memiliki, merasa bangga menjadi bagian dari organisasi, kesediaan untuk berusaha sungguh-sungguh untuk mensukseskan organisasi dan loyalitas yang tinggi terhadap organisasi; merevisi anggaran apabila diperlukan melalui penambahan atau pengurangan pagu anggaran, pergeseran rincian angaran, dan perubahan atau ralat karena kesalahan administrasi sehingga efektivitas pengelolaan anggaran dapat tercapai.

Hasil nilai adjusted $\mathrm{R}^{2}$ sebesar 0,532 yang berarti variabel kompetensi sumber daya manusia, pemanfaatan teknologi informasi, komitmen organisasi dan revisi anggaran hanya mampu menjelaskan variasi variabel efektivitas pengelolaan anggaran sebesar $53,20 \%$ sehingga masih ada 46,80\% variasi variabel efektivitas 
pengelolaan anggaran dijelaskan oleh variabel lain yang tidak dimasukkan dalam model. Penelitian selanjutnya hendaknya mempertimbangkan variabel bebas lain yaitu variabel luar pengelola anggaran (variabel eksogen) yang diduga dapat memperkuat penjelasan efektivitas pengelolaan anggaran Universitas Udayana antara lain gaya kepemimpinan, reward dan punishment bagi unit kerja untuk keberhasilan/kegagalan pengelolaan anggaran dan Sistem Pengendalian Intern. Penelitian ini menggunakan teknik analisis regresi linier berganda, untuk penelitian berikutnya juga dapat mempertimbangkan penggunaan Teknik Analisis Regresi Moderasi dengan Revisi Anggaran sebagai variabel pemoderasi.

\section{REFERENSI}

Angle, H.L. and Perry, J.L. 1981. An Empirical Assessment of organizational Commitment and Organizational Effectiveness. Administrative Science Quarterly, 26(1): 1-14.

Andriani, W. 2010. Pengaruh Kapasitas Sumber Daya Manusia dan Pemanfaatan Teknologi Informasi Terhadap Keterandalan dan Ketepatwaktuan Laporan Keuangan Pemerintah Daerah. Jurnal Akuntansi dan Manajemen, 5(1): 69 - 80.

Arif, E., Halim. A. 2013. Identifikasi Faktor-faktor Penyebab Minimnya Penyerapan Anggaran Pendapatan dan Belanja Daerah (APBD) Kabupaten/Kota di Provinsi Riau Tahun 2011. Simposium Nasional Akuntansi XVI. Manado. 25-28 September 2013.

Azmi, G. 2014. Pengaruh Kejelasan Sasaran Anggaran, Kualitas Sumberdaya Manusia dan Komitmen Organisasi terhadap Kinerja Pengelolaan Keuangan Daerah di Lingkungan Pemerintah Aceh. Jurnal Magister Akuntansi Pascasajana Universitas Syah Kuala, 3(4) : $10-22$.

Adamy, M. 2010. Pengaruh Partisipasi Anggaran, Kepemimpinan, dan Komitmen Organisasi terhadap Kinerja Manajerial pada SKPD Kota Lhokseumawe. Jurnal Aplikasi Manajemen, 8(4) : 1133 - 1142.

Baihaqi, 2012. Pengaruh Komitmen Organisasi dan Peran Manajerial Pengelolaan Keuangan Daerah terhadap Kinerja Manajerial Satuan Kerja Perangkat Daerah. Jurnal Fairness, 1(3): 243-253. 
Chong, V. K., dan Chong, K.M. 2002. Budget Goal Commitment and Informational Effect of Budget Participation on Performance: A Structural Equation Modeling Approach. Behavioral Research In Accounting, 14(1): 6586.

Caers, R., Bois, C.D, Jegers, M., Gieter, S.D., Schepers, C., Pepermans, R. 2006. Principal-Agent Relationships on the Stewardship-Agency Axis. Nonprofit Management and Leadership, 17(1): 25-47.

Donaldson, L., \& Davis, J.H. 1989. CEO governance and shareholder returns: Agency theory or stewardship theory. Paper presented at the annual meeting of the Academy of Management, Washington, DC.

Donaldson L., Davis, J.H., Schoorman, F.D. 1997. Toward A Stewardship Theory Of Management. Journal Academy of Management Review, 22(1): 20-47.

Donnelly, M., Dalrymple, J.F., Hollingsworth, I.P. 1994. The Use and Development of Information Systems and Technology in Scottish Local Government. International Journal of Public Sector Management, 7(3): 4-15.

Donaldson, L., \& Davis, J. H. 1991. Stewardship Theory or Agency Theory: CEO Covernance and Shareholders Return. Australian Journal of Management, 16(1): $49-65$

Dewi, D.A.R, 2010. "Pengaruh Kompetensi Sumber Daya Manusia, Sistem Administrasi Keuangan Daerah, Sarana dan Prasarana pada Efektivitas Pengelolaan Keuangan Daerah Kabupaten Badung” (tesis). Denpasar: Universitas Udayana.

Fahlevi, H., Ananta, R. M. 2015. Analisis Efisiensi dan Efektifitas Anggaran Belanja Langsung - Studi pada SKPD di Pemerintah Kota Banda Aceh. Jurnal Ilmiah Administrasi Publik FIA UB, 1(2): 37-44.

Grant, G.H., Miller, K.C, Alali, F. 2008. The effect of IT controls on financial reporting. Managerial Auditing Journal, 23(8): 803-823.

Ghozali, I. 2013. Aplikasi Analisis Multivariate dengan Program IBM SPSS 21. Semarang: Badan Penerbit Universitas Diponegoro.

Herriyanto, H. 2012. "Faktor-faktor yang mempengaruhi keterlambatan penyerapan anggaran belanja pada Satuan Kerja Kementerian/Lembaga di wilayah Jakarta" (tesis). Jakarta: Universitas Indonesia.

Hullah, A.R. 2012. Pengaruh Sumber Daya Manusia dan Pemanfaatan Teknologi Informasi Terhadap Keterandalan Pelaporan Keuangan pada Pemerintah Provinsi Sulawesi Utara. Jurnal Riset Akuntansi dan Auditing Unsrat, 3(2): 9-21. 
Husein, F. 2003. Sistem Informasi Akuntansi. Yogyakarta: UPP Akademi Manajemen Perusahaan YKPN

Halim, A. 2004. Manajemen Keuangan Daerah. edisi revisi. Yogyakarta: UPP AMP YPKN.

Indiana, F. 2010. Analisis Faktor-Faktor yang mempengaruhi Efektivitas Pelaksanaan Anggaran pada Perusahaan-Perusahaan Manufaktur di Klaten. Jurnal Universitas Muhammadiyah.

Iskandar, J. 2015. Pengaruh Sistem Pengendalian Intern Pemerintah, Kompetensi Sumber Daya Manusia dan Pengawasan Fungsional Terhadap Efektivitas Pengelolaan Keuangan Daerah.(Studi Empiris Pada Satuan Kerja Perangkat Daerah Kota Pekanbaru).Jurnal Jom Fekon Universitas Riau, 2(2).

Jogiyanto, 1995. Analisa dan Desain Sistem Informasi: Pendekatan Terstruktur Teori dan Praktek Aplikasi Bisnis. Yogyakarta: Andi Offset.

Jogiyanto. 2003. Sistem Teknologi dan Informasi. Yogyakarta: Andi.

Jurnali, T., Supomo, B. 2002. Pengaruh Faktor Kesesuaian Tugas Teknologi dan Pemanfaatan TI terhadap Kinerja Akuntan Publik. Jurnal Riset Akuntansi Indonesia, 5(2): 214-228.

Jasman, 2012. Pengaruh Partisipasi Anggaran dan Komitmen Organisasi Terhadap Efektivitas Pengelolaan Anggaran Alat dan Bahan Pembelajaran (Studi empiris pada Akademi Teknik Soroako). Jurnal Hipotesis (ISSN 2085-465X), 4(3).

Lim, F.P. C. 2013. Impact of Information Technology on Accounting Systems. AsiaPacific Journal of Multimedia Services Convergent with Art, Humanities, and Sociology, 3(2): 93-106.

Mowday, R. T., Steers, R. M., Porter, L. W. 1979. The Measurement of Organizational Commitmen. Journal of Vocational Behaviour, 14: 224-247.

Mahsun, M. 2009. Pengukuran Kinerja Sektor Publik. Yogyakarta: BPFE.

Morgan, D., Bacon, Kelly G., Bunch, R., Cameron, Charles, Deis, R. 1996. What Middle Managers Do In Local Government: Stewardship of The Public Trust and Limits of Reinventing Government. Public Administration Review, 56(4): 359-366.

Mardiasmo. 2009. Akuntansi Sektor Publik. Edisi 4.Yogyakarta : Andi.

Malahayati, C. 2015. Pengaruh Kapasitas Sumber Daya Manusia, Perencanaan Anggaran dan Pelaksanaan Anggaran Terhadap Serapan Anggaran Satuan Kerja 
Perangkat Daerah(SKPD) pada Pemerintah Kota Banda Aceh. Jurnal Magister Akuntansi Pascasajana Universitas Syah Kuala, 4(1): 11 - 19.

Nouri, H. and Parker, R. J. 1998. The Relationship Between Budget Participation and Job Performance : The Roles of Budget Adequacy and Organizational Commitment. Accounting, Organizations and Society, 2(5-6): 467-483.

Peraturan Menteri Dalam Negeri Republik Indonesia nomor 690.900-327 Tahun 1996 tentang Pedoman Penilaian Kinerja Keuangan.

Peraturan Menteri Keuangan Republik Indonesia nomor 15 tahun 2016 tentang Tata Cara Revisi Anggaran tahun 2016.

Porter, L.W., Steers, R.M., Mowday, R.T., Boulian, P.V.1974. Organizational commitment, job satisfaction and turnover among psychiatric technicians. Journal of Applied Psychology, 59(5): 603-609.

Pratikyo, A.N.D. 2016. Pengaruh Partisipasi Anggaran, Teknologi Informasi, dan Kualitas Informasi Manajemen terhadap Kinerja Manajerial (Studi Empiris ada Perusahaan Manufaktur di Kabupaten Pati). Serat Acitya - Jurnal Ilmiah Untag Semarang, 5(1) : $84-99$.

Riyanti, Y. 2015. Pengaruh Pemahaman Akuntansi, Pemanfaatan Teknologi Informasi, dan Peran Internal Audit Terhadap Efektivitas Penyusunan Laporan Keuangan Pada Satuan Kerja Mahkamah Syar'iyah di Aceh.Jurnal Magister Akuntansi Pascasarjana Universitas Syah Kuala, 4(2): 80-90.

Rahayu, S. L., Siswanto, A. D. 2010. Faktor-Faktor Penyebab Rendahnya Penyerapan Belanja Kementerian/Lembaga TA 2010. Policy paper Badan Kebijakan Fiskal, Kementerian Keuangan. Jakarta.

Sugiyono. 2014. Metode Penelitian Bisnis. Bandung : Alfabeta.

Sunaryo, A. 2006. Pengaruh variabel-variabel Karakteristik Anggaran terhadap Efektifitas Pelaksanaan Anggaran pada PT. (PERSERO) Pelabuhan Indonesia III. Jurnal Ekuitas Sekolah Tinggi Ilmu Ekonomi Indonesia (STIESIA) Surabaya, 10(4): $515-536$.

Sumarno, J. 2005. Pengaruh Komitmen Organisasi dan Gaya Kepemimpinan terhadap Hubungan Antara Partisipasi Anggaran dan Kinerja Manajerial. SNA VIII Solo.

Thornton, D.D. 2009. Stewardship in Government Spending: Accountability, Transparency, Earmarks, and Competition. Public Interest Institute, : 9(1): 1-33.

Tim Penyusun Renstra. 2014. Rencana Strategis Universitas Udayana Tahun 2015 - 2019. Badung: Universitas Udayana. 
Undang-Undang Republik Indonesia nomor 17 tahun 2003 tentang Keuangan Negara.

Undang-Undang Republik Indonesia nomor 1 tahun 2004 tentang Perbendaharaan Negara.

Undang-Undang Republik Indonesia nomor 15 tahun 2004 tentang Pemeriksaan Pengelolaan dan Tanggung Jawab Keuangan Negara.

Van Slyke, D. M. 2006. Agents or Stewards: Using Theory to Understand the Government-Nonprofit Social Service Contracting Relationship. Journal of Public Administration Research and Theory,17(2): 157-187.

Vargas, S.A. 2004. Development of Corporate Governance Systems: Agency Theory versus Stewardship Theory in Welsh Agrarian Cooperative Societies, U: 4th Annual Conference of EURAM (European Academy of Management), 5-9 May 2004, St. Andrews, Scotland, str. 1-20.

Wiener, Y. 1982. Commitment in Organization : A Normative View. Academy of Management Review, 7(3): 418-428.

Wentzel, K. 2002.The Influence of Fairness Perceptions and Goal Commitment on Manager's Performance in a Budget Setting. Behavioral Research In Accounting, 14(1): 247-271.

Wilson, K.R. 2010. Steward Leadship: Characteristics of The Steward Leader in Christian Nonprofit Organizations. A Dissertation Presented for the Degree of $\mathrm{PhD}$ at The University of Aberdeen.

World Bank, 2012. Identifikasi hambatan dalam pelaksanaan anggaran di sektor infrastruktur di Jakarta. http://documents.worldbank.org/curated/en/378351468285051070/Identifikasihambatan-dalam-pelaksanaan-anggaran-di-sektor-infrastruktur-studi-penelusuran$\underline{\text { DIPA }}$

Yaswat, L. 2015. Pengaruh Kompetensi Sumber Daya Manusia (SDM), Sistem Pengendalian Internal Pemerintah (SPIP), dan Penerapan Sistem Akuntansi Keuangan Daerah (SAKD) terhadap Efektivitas Pengelolaan Keuangan Daerah (Studi Empiris pada Satuan Kerja Perangkat Daerah Kabupaten Tanah Datar Provinsi Sumatera Barat). Jurnal Jom Fekon Universitas Riau, 2(2).

Yeyen, AZ. 2013. Pengaruh Revisi Anggaran, Partisipasi Anggaran, Tingkat Kesulitan, serta Evaluasi dan Umpan Balik terhadap Pencapaian Anggaran yang Efektif (Studi Empiris Pada Satuan Kerja Perangkat Daerah Kota Payakumbuh). Jurnal Universitas Negeri Padang.

Yuniarti, E., Saty, F.M. 2008. Pengaruh Komitmen Organisasi terhadap Hubungan 
I Wayan Sukarta, I Dewa Nyoman Badera dan Ni Made Dwi Ratnadi. Pengaruh ........

antara Partisipasi Anggaran dan Kinerja Manajerial. Jurnal Ilmiah Essai (ISSN No. 1978-6034), 2(1) 